\title{
Correction to: A review on electric vehicles and their interaction with smart grids: the case of Brazil
}

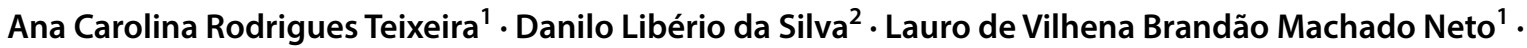 \\ Antonia Sonia Alves Cardoso Diniz ${ }^{1}$. José Ricardo Sodré ${ }^{1}$
}

Published online: 12 September 2018

(c) Springer-Verlag GmbH Germany, part of Springer Nature 2018

\section{Correction to: \\ Clean Techn Environ Policy (2015) 17:841-857 \\ https://doi.org/10.1007/s10098-014-0865-x}

In the original publication, the article was mistakenly published under the category "Perspective". However, the correct category of the article is "Review".

The original article can be found online at https://doi.org/10.1007/ s10098-014-0865-x.

José Ricardo Sodré

ricardo@pucminas.br

Ana Carolina Rodrigues Teixeira

acrt88@hotmail.com

Danilo Libério da Silva

danilo.silva@ fiat.com.br

Lauro de Vilhena Brandão Machado Neto

lvilhena@pucminas.br

Antonia Sonia Alves Cardoso Diniz asacd@pucminas.br

1 Department of Mechanical Engineering, Pontifical Catholic University of Minas Gerais, Av. Dom José Gaspar, 500, Belo Horizonte, MG 30535-901, Brazil

2 Fiat Automóveis S.A., Costs Engineering - Electric and Electronics, Av. Contorno, 3455, Betim, MG 32699-900, Brazil 